\title{
THE INFLUENCE OF LEMON (Citrus Limon (L.)) IRON ION (Fe) REMOVAL ON STAINLESS STEEL ORTHODONTIC WIRE
}

\author{
Chiquiteta Mariska Chairunnisa *, R Rama Putranto**, Moh Husnun Niam ${ }^{* * *}$
}

*Program Pendidikan Dokter Gigi Fakultas Kedokteran Gigi Universitas Islam Sultan Agung

**Departemen Orthodonti Fakultas Kedokteran Gigi Universitas Islam Sultan Agung

${ }^{* * *}$ Departemen Ilmu Kesehatan Gigi Masyarakat Fakultas Kedokteran Gigi Universitas Islam Sultan Agung

Correspondence: rama.putranto@unissula.ac.id

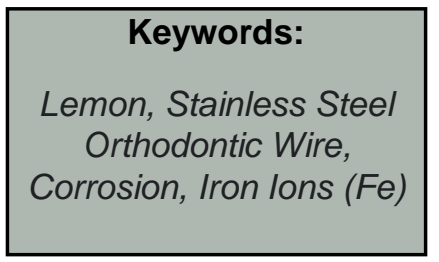

\begin{abstract}
Background: Lemons consist of 5-8\% citric acid, have a pH of around 2.74. Drinks that have a critical $\mathrm{pH}$ of 5.5 can be said to be acidic drinks. Acidic drinks have the potential to cause corrosion of teeth and dental materials, one of which is stainless steel orthodontic wire. Stainless steel orthodontic wire is easily corroded, the wire has a composition of 71\% Iron (Fe), 18\% Chromium (Cr), 8\% Nickel (Ni), and 0.2\% Carbon (C). Corrosion is caused by the presence of inorganic components that act as electrolyte media that can trigger electrochemical reactions.

Method: Each sample was placed on each uninsulated petridish and labeled as a marker. This is done by inserting orthodontic wire which is immersed into the incubator for 3.5 hours at $37^{\circ} \mathrm{C}$. Then the sample is taken and the separation between the sample and the solution is carried out. After that, the measurement of Iron ( $\mathrm{Fe}$ ) ions was carried out using the Atomic Absorption Spectrophotomery tool.
\end{abstract}

Result: The results showed the average release of Iron ( $\mathrm{Fe}$ ) ions in the experimental group of lemon juice with a concentration of $25 \%$ was $0.067 \mathrm{mg} / \mathrm{L}$, a concentration of $50 \%$ was $0.090 \mathrm{mg} / \mathrm{L}$ and a concentration of $100 \%$ was $0.135 \mathrm{mg} / \mathrm{L}$. The test results obtained using the One Way Anova test showed that there was no significant difference $(p>0.05)$.

Conclusion: There was no significant difference in the release of Iron $(F e)$ ions in stainless steel orthodontic wires between experimental groups, and there was no effect of soaking lemon juice (Citrus Limon (L.)) on the release of Iron ( $\mathrm{Fe})$ ions in stainless steel orthodontic wires.

\section{PENDAHULUAN}

Saat ini masyarakat sudah banyak yang mengkonsumsi air buah jeruk lemon, buah lemon sudah menjadi buah yang diminati oleh sebagian masyarakat. Buah lemon sendiri dapat ditemui dalam berbagai bentuk seperti olahan infused water, minuman botol, campuran makanan atau buahnya dapat dimakan langsung ${ }^{(1)}$.

Buah lemon terdiri dari 5-8\% asam sitrat, yang memiliki $\mathrm{pH}$ sekitar 2,74. Minuman yang memiliki $\mathrm{pH}$ kritis yaitu $\leq 5,5$ dapat dikatakan sebagai minuman yang asam ${ }^{(2)(3)}$. Minuman asam dapat berpotensi menyebabkan korosi pada gigi maupun bahan kedokteran gigi salah satunya yaitu kawat ortodonti stainless steel, karena dapat mengubah kekasaran pada permukaan tersebut ${ }^{(4)}$.

Kawat ortodonti yang paling sering digunakan saat ini adalah kawat yang berbahan stainlees steel, karena memiliki kekuatan yang tinggi, tahan terhadap korosi, dan biaya yang relatif murah $^{(5)}$. Kawat ortodonti ini dikenal sebagai baja yang tahan terhadap korosi, kawat tersebut memiliki komposisi yaitu $71 \%$ Besi (Fe), 18\% Kromium (Cr), 8\% Nikel (Ni), dan 0,2\% Karbon $(C)^{(6)}$. 
Faktor yang dapat mempercepat terjadinya proses korosi yaitu kelembaban yang tinggi, temperatur yang hangat, jumlah oksigen pada sekitar, larutan elektrolit yang lemah, $\mathrm{pH}$ yang asam, serta zat kimia yang ada di sekitarnya ${ }^{(8)}$. Sifat tahan terhadap korosi pada kawat ortodonti dapat dipengaruhi oleh makanan/minuman yang memiliki $\mathrm{pH}$ rendah adalah buah lemon ${ }^{(6)}$.Oleh karena itu, peneliti tertarik untuk meneliti apakah ada pengaruh perendaman air buah jeruk lemon (Citrus Limon (L.)) terhadap pelepasan ion Besi (Fe) pada kawat ortodonti stainless steel.

Korosi adalah hasil pertemuan atau reaksi kimia secara terus menerus antara logam atau material dengan lingkungan yang asam, basa atau garam $^{(7)}$. Korosi juga dapat menurunkan kekuatan dari logam, menurunkan estetik serta bentuk fisik yang akan berubah ${ }^{(8)}$. Korosi logam pada rongga mulut termasuk ke dalam korosi basah atau elektrokimia. Proses terjadinya korosi kawat ortodonti stainless steel yang berada pada rongga mulut akan melepaskan ion-ion yang terkandung di dalam kawat tersebut ${ }^{(9)}$.

Tujuan penelitian ini adalah untuk mengetahui pengaruh perendaman air buah jeruk lemon (Citrus Limon (L.)) terhadap pelepasan ion Besi $(\mathrm{Fe})$ pada kawat ortodonti stainless steel.

\section{METODE PENELITIAN}

Berdasarkan Ethical Clearance No. 1593/A.1/SA-FKG/XI/2020 penelitian ini merupakan penelitian dengan jenis metode pra eksperimental tanpa adanya kelompok control dengan rancangan one shot case study. Penelitian ini menggunakan kawat stainless steel dengan produk American Orthodontics diameter 0,016 inchi. Sampel dibagi menjadi 3 kelompok percobaan yang direndam dalam air buah jeruk lemon dengan konsentrasi $25 \%$, 50\% dan 100\%.
Perhitungan besar sampel berdasarkan rumus Daniel (1987), yang didapatkan jumlah 4 sampel pada setiap kelompok. Didapatkan jumlah total sampel yang sebanyak 12 sampel.

Instrument yang digunakan pada penelitian yaitu: Atomic Absorption Spectrophotometry (AAS), pH Meter Digital (Lutron PH-222), Inkubator (Memmert), Tang Potong, Petridish Tidak Bersekat, Kaca Pengaduk, Corong Gelas, Penggaris, Handscoon, Masker, Gelas Ukur (Pyrex, Indonesia), Gelas Kimia $100 \mathrm{ml}$ x $500 \mathrm{ml}$ (Pyrex, Indonesia), kawat ortodonti stainless steel, perasan air jeruk lemon dengan konsentrasi $25 \%$, $50 \%$, dan $100 \%$.

Penelitian ini diawali dengan pemotongan kawat ortodonti stainlesss steel dengan Panjang $11,6 \mathrm{~cm}$. Selanjutnya dilakukan pengukuran derajat keasaman larutan menggunakan $\mathrm{pH}$ meter digital. Hasil pengukuran didapatkan rerata pada konsentrasi $25 \%$ dengan $\mathrm{pH} 2,42$, konsentrasi 50\% dengan $\mathrm{pH} 2,56$ dan konsentrasi $100 \%$ dengan $\mathrm{pH}$ 2,32. Kelompok perlakuan direndam dengan menggunakan rumus pelarutan yaitu $\mathrm{V} 1 \times \mathrm{M} 1=\mathrm{V} 2$ x M2. Selanjutnya untuk setiap sampel ditempatkan pada masing-masing petridish tidak bersekat dan diberi label sebagai penanda. Dilakukan dengan cara memasukkan kawat ortodonti yang dilakukan perendaman ke dalam inkubator selama 3,5 jam dengan suhu $37^{\circ} \mathrm{C}$. Kemudian sampel diambil dan dilakukan pemisahan antara sampel dengan larutan. Setelah itu, dilakukan pengukuran ion Besi (Fe) dengan menggunakan alat Atomic Absorption Spectrophotomery.

Analisis penelitian menggunakan uji parametrik menggunakan Saphiro Wilk untuk normalitas dan Levene's Test untuk homogenitas dan dilanjutkan dengan uji One Way Anova. Penelitian dilakukan di Laboratorium Mikrobiologi 
Fakultas Kedokteran UNISSULA, Laboratorium Kimia Fakultas Kedokteran UNISSULA, Laboratorium Teknik Lingkungan UNDIP.

\section{HASIL PENELITIAN}

Hasil pengukuran jumlah pelepasan ion

Besi $(\mathrm{Fe})$ pada kawat ortodonti stainless steel yang direndam air buah jeruk lemon pada tabel 1 .

Tabel 1. Rerata pelepasan ion Besi (Fe)

\begin{tabular}{ccc}
\hline Kelompok & $\begin{array}{c}\text { Jumlah } \\
\text { Sampel }\end{array}$ & $\begin{array}{c}\text { Mean } \pm \text { Std. } \\
\text { Deviation }\end{array}$ \\
\hline $\mathrm{K} 25 \%$ & 4 & $0,067 \pm 0,072$ \\
\hline $\mathrm{K} 50 \%$ & 4 & $0,090 \pm 0,053$ \\
\hline $\mathrm{K} 100 \%$ & 4 & $0,135 \pm 0,060$
\end{tabular}

Berdasarkan tabel 1 rerata jumlah pelepasan ion Besi $(\mathrm{Fe})$ pada 12 sampel kawat ortodonti stainless steel mengalami hasil diatas standar deviasi. Rerata pelepasan ion Besi $(\mathrm{Fe})$ terbesar pada air jeruk lemon dengan konsentrasi $100 \%$, dan rerata terkecil pada air jeruk lemon dengan konsentrasi $25 \%$.

Tabel 2. Hasil uji normalitas Saphiro Wilk

\begin{tabular}{lll}
\hline Kelompok & Sig. (P) & Keterangan \\
\hline $\mathrm{K} 25 \%$ & 0,214 & $\begin{array}{l}\text { Data } \\
\text { terdistribusi } \\
\text { normal }\end{array}$ \\
& & Data \\
& terdistribusi \\
& normal \\
\hline $\mathrm{K} 50 \%$ & 0,134 & Data \\
& & terdistribusi \\
& & normal \\
\hline
\end{tabular}

Hasil uji normalitas dilakukan dengan menggunakan uji Saphiro Wilk karena jumlah total sampel yang digunakan $<50$ buah. Sesuai dengan hasil uji normalitas tabel 2 dapat diartikan kelompok perlakuan terdistribusi dengan normal dengan nilai $p>0,05$.

Tabel 3. Hasil uji homogenitas Levene's Test

\begin{tabular}{lcc}
\hline Kenaikan Skor & Sig. & Keterangan \\
\hline $\begin{array}{l}\text { Based on } \\
\text { Mean }\end{array}$ & 0,855 & Data homogen \\
\end{tabular}

Hasil uji homogenitas dengan menggunakan Levene's Test didapatkan hasil mean 0,855 dengan nilai $\mathrm{P}>0,05$ dapat diartikan bahwa sebaran semua data kelompok homogen.

Tabel 4. Hasil uji One Way Anova

\begin{tabular}{lclc}
\hline Kelompok & $P$ & $\begin{array}{l}\text { Sig } \\
(P<0,05)\end{array}$ & Keterangan \\
\cline { 1 - 1 } K 25\% & \multirow{2}{*}{0,339} & $P>0,05$ & $\begin{array}{c}\text { Tidak } \\
\text { K 50\% }\end{array}$ \\
\cline { 1 - 1 } K 100\% & & & Signifikan \\
\hline
\end{tabular}

Berdasarkan tabel 4 dengan 3 kelompok pengujian didapatkan hasil 0,339 dengan nilai $P>0,05$ atau dapat diartikan tidak terdapat perbedaan yang signifikan pada pelepasan ion Besi $(\mathrm{Fe})$ pada kawat ortodonti stainless steel antar kelompok percobaan.

\section{DISKUSI}

Pada hasil rerata yang didapat menunjukkan pelepasan ion Besi ( $\mathrm{Fe}$ ) tertinggi pada kelompok air jeruk lemon dengan konsentrasi 100\% yaitu 0,135 sedangkan rerata pelepasan ion Besi $(\mathrm{Fe})$ terendah pada kelompok air jeruk lemon dengan konsentrasi 25\% didapatkan 0,067. Semakin besar konsentrasi air buah jeruk lemon 
maka semakin besar pelepasan ion Fe atau dapat dikatakan berbanding lurus ${ }^{(10)}$.

Sesuai dengan uji yang telah dilakukan, didapatkan hasil uji One Way Anova yaitu 0,339 yang artinya $p>0,05$ dan dapat dikatakan hasil penelitian yang telah dilakukan tidak ada perbedaan yang signifikan pada pelepasan ion Besi $(\mathrm{Fe})$ pada kawat ortodonti stainless steel antar kelompok percobaan.

Pelepasan ion Besi $(\mathrm{Fe})$ dari kawat ortodontik stainless steel dapat menyebabkan terjadinya proses korosi, karena adanya perendaman kawat didalam cairan yang bersifat asam atau $\mathrm{pH}$ yang rendah ${ }^{(11)}$. Kandungan Besi (Fe) yang dominan dalam kawat ortodontik stainless steel menyebabkan terjadi pelepasan ion Besi $(\mathrm{Fe})$ yang besar saat dilakukan perendaman didalam air buah jeruk lemon terhadap kekuatan kawat ortodontik stainless steel dalam fungsinya ${ }^{(12)}$.

Secara teori $\mathrm{pH}$ asam menyebabkan kerusakan dari lapisan pelindung kawat ortodontik stainless stee/(13). Larutan asam memiliki kemampuan dalam merusak lapisan oksidasi dari logam. Adanya protein juga dapat mempengaruhi terjadinya pelepasan ion logam karena protein dapat berperan sebagai media elektrolit yang dapat memicu terjadinya reaksi kimia $^{(14)}$. Reaksi pelepasan pada ion $\mathrm{Fe}$ melibatkan anoda dan katoda, anoda merupakan bagian yang akan teroksidasi dan katoda merupakan bagian yang akan tereduksi. Pada reaksi elektrokimia dari kawat ortodontik stainless steel yang menjadi anoda adalah ion logam dan $\mathrm{H}^{+}$dari media elektrolit sebagai katoda.

\section{KESIMPULAN}

1. Tidak terdapat perbedaan yang signifikan pada pelepasan ion Besi $(\mathrm{Fe})$ pada kawat ortodonti stainless steel antar kelompok percobaan

2. Tidak terdapat pengaruh perendaman air buah jeruk lemon (Citrus Limon (L.)) terhadap pelepasan ion Besi (Fe) pada kawat ortodonti stainless steel.

\section{UCAPAN TERIMAKASIH}

Penulis mengucapkan terima kasih kepada seluruh dosen dan staf karyawan Fakultas Kedokteran Gigi Universitas Islam Sultan Agung Semarang yang telah mendidik dan membantu selama menuntut ilmu masa pendidikan Sarjana Kedokteran Gigi.

\section{DAFTAR PUSTAKA}

1. Ardiyanti, A. (2018). Manfaat Lemon dalam Dunia Pertanian dan Kesehatan, (May), $1-$ 3.

2. Harifah, I., Mustofa, A., \& Suhartatik, N (2017). Aktivitas Antioksidan Infused Water Dengan Variasi Jenis Jeruk (Nipis, Lemon, Baby) Dan Buah Tambahan (Stroberi, Anggur Hitam, Dan Kiwi), 1(1).

3. Hutasoit. (2005). Buah Segar Musim.

4. Kurniawati, A. C. (2014). Pengaruh perendaman infused water dan penyikatan

5. Wasono, N. P., Assa, Y. A., \& Anindita, P. S. (2016). Pelepasan Ion Nikel Dan Kromium Bracket Stainless Stell Yang Direndam Dalam, 5(1), 158-163.

6. Kristianingsih, R., Joelijanto, R., Praharani, D., Gigi, F. K., \& Unej, U. J. (2014). Analisis Pelepasan Ion Ni dan Cr Kawat Ortodontik Stainless Steel yang Direndam dalam Minuman Berkarbonasi ( Analysis of Ion Release Nickel and Chromium of Orthodontics Stainless Steel Wire Immersed by Carbonated Drink ).

7. Rotor, J. (2011). Sumarji, Jurnal ROTOR, Volume 4 Nomor1, Januari 2011 1, 4, 1-8.

8. Canina, L., \& Pudyani, P. S. (2003). Pengaruh Kontaminasi Korosi.Pdf.

9. Iws, P., \& Suparwitri, S. (2013). Sebelum Dan Setelah Perendaman Dalam Saliva Buatan Pada Periode Waktu Yang Berbeda ( Studi Laboratoris In Vitro ), 4, 136-141.

10. Fahlafi, R. (2019) Analisa Pengaruh Ph Lingkungan Terhadap Laju Korosi Dan Waktu Sisa Pada Heat Affected Zone Akibat Pengelasan Smaw Spec. Pipa Api 
5I Grade B. Politeknik Perkapalan Negeri Surabaya.

11. Fahlafi, R. (2019) Analisa Pengaruh Ph Lingkungan Terhadap Laju Korosi Dan Waktu Sisa Pada Heat Affected Zone Akibat Pengelasan Smaw Spec. Pipa Api 5I Grade B. Politeknik Perkapalan Negeri Surabaya

12. Harmintaswa, I. (2020) Pelepasan Ion Fe (Ferrum) pada Kawat Stainless Steel Ortodonti yang Direndam Dalam Minuman Air Kelapa Kemasan. Universitas Jember.

13. Sharma, M. R. et al. (2018) 'Effect of fruit juices and chloride ions on the corrosion behavior of orthodontic archwire', Materials Technology. Taylor \& Francis, pp. 1-7. doi: 10.1080/10667857.2018.1473992.

14. Sumule, I., Anindita, P.S., \& Waworontu, O. A. (2015). Pelepasan Ion Nikel Dan Kromium Braket Stainless Steel Yang Direndam Dalam Minuman Berkarbonasi. Jurnal e-Gigi, 3(2): 464-468. 